Nordiska ministerrådet

Ved Stranden 18

DK-1061 København K

www.norden.org

NORDISKE ARBEJDSPAPIRER

NOR D ISKA ARBETSPAPPER

\title{
Nordiska samarbetet för barn och unga
}

-historien om hur samarbetet växte fram

David Berjlund

http://dx.doi.org/10.6027/NA2014-918

NA2014:918

ISSN 2311-0562 



\section{BARN- OCH \\ UNGDOMSPOLITISKT \\ ARBETE I NORDEN \\ Hur det nordiska samarbetet kring barn- och ungdomsfrågor växte fram}


INNEHÅLLSFÖRTECKNING:

INLEDNING

sida 3

DET NORDISKA SAMARBETET VÄXER FRAM MED BARN - OCH UNGDOMSFRÅGORNA PÅ AGENDAN sida 4

BARN OCH UNGA - ETT EGET OMRÅDE sida 6

BARN- OCH UNGDOMSFRÅGORNA I

CENTRUM AV DET NORDISKA SAMARBETET sida 11

$\mathrm{NU}$ - OCH SNART sida 17 


\section{INLEDNING}

Nordiska barn- och ungdomskommittén, NORDBUK, är ministerrådets rådgivande och samordnande organ för barn- och ungdomspolitiska frågor. NORDBUK har funnits från mars 2006, men de barn- och ungdomspolitiska frågornas historia i det nordiska samarbetet är lång. I planer och dokument, bidragsordningar och avsiktsförklaringar syns avtrycken, och en utveckling där barns och ungas perspektiv tagit en allt större och mer central plats - från Helsingforsavtalets formuleringar om "vård av barn och unga" till barn- och ungdomsperspektivet som utgångspunkt för ministerrådets alla sektorer.

Denna skrift försöker svara på frågorna om varför nordiska länder arbetar tillsammans med barn- och ungdomsfrågor och hur detta arbete har utvecklats. Den behandlar olika delar av det nordiska samarbetet, men fokuserar speciellt Nordiska ministerrådet och NORDBUK. Det första kapitlet tecknar en historisk bakgrund och berättar om början av det nordiska samarbetet - generellt och runt barn- och ungdomsfrågor. I det andra kapitlet handlar det om hur barn- och ungdomsfrågorna kvalificerades, fick tydligare former och alltmer plats. Det tredje och längsta kapitlet tittar närmare på detaljer och formalia, och börjar i mars 2006. Då avlöstes den tidigare ungdomskommittén av NORDBUK, som fick betydligt större möjligheter, och samtidigt antog ministerrådet för första gången en strategi för barn och unga i Norden. I ett avslutande kapitel tecknas nuläget vid årsskiftet 2013-2014. 


\section{DET NORDISKA SAMARBETET VÄXER FRAM - \\ MED BARN- OCH UNGDOMSFRÅGORNA PÅ AGENDAN}

\section{Om Norden, 1900-talets demokratiska genombrott och folkligt samarbete över nationsgränser som förutsättning och bakgrund till både det officiella nordiska samarbetet och barn- och ungdomsfrågornas betydelse.}

Norden är stort, det sträcker sig från Falsters sydspets till Nordkap, från Joensuu i östra Finland till Island, och vidare till Grönland i väst. Nordens historia rymmer isolering och kontakt, handel och krig, staterna har sett olika ut, man har styrt över varandra, unioner har bildats och upplösts. För vanligt folk, speciellt i gränstrakter, spelade inte alltid nationstillhörigheten så stor roll, de politiska kontakterna var i århundraden endast en fråga för makthavare, kungar och befälhavare.

Men från 1800-talets slut fanns samarbeten av helt andra slag, mellan folkliga rörelser och organisationer som inte hade makten. Föreningen Norden bildades i alla de fem nordiska länderna mellan 1919 och 1924, vänorter uppstod och arbetarrörelsens organisationer sökte nordiskt samarbete. Norge lämnade unionen med Sverige 1905 och Island blev en självständig stat 1944. Mellan dessa två årtal påverkades Norden i grunden av två världskrig, ockupation, finskt inbördeskrig - och av ett brett demokratiskt genombrott med demokratiska val, parlamentarism och lagstadgade rättigheter, liksom med jämlikhetsideal och delaktighet i samhället genom organisationer och folkrörelser. När Nordiska rådet grundades 1952, som ett samarbetsorgan för de nordiska parlamenten, handlade det om nordiskt samarbete på toppnivå, men förutsättningen var att de nordiska folken tagit makten i sina länder.

Demokratin släppte fram fler röster. Det påverkade vad som sågs som centralt, också i det expanderande nordiska samarbetets innehåll och karaktär under 1900-talet. Det blev inget nordiskt försvarsförbund, ingen ekonomisk union - men samarbete blev det. Ofta runt 
praktiska frågor, ofta präglat av politiska idéer som handlade om omsorg, vård och välfärd.

I mars 1962 signerade de nordiska länderna Helsingforsavtalet som skulle bli en grund för det fortsatta samarbetet. I Helsingforsavtalets artikel 16, under rubriken Socialt samarbete, skriver man att länderna "skola ytterligare utveckla samarbetet beträffande hälso- och sjukvård, nykterhetsvård samt vård av barn och ungdom."

Tio år senare fanns de tre stora nordiska samarbetsinstitutionerna på plats: parlamentens Nordiska rådet fick 1966 sällskap av Nordiska kulturfonden och 1971 grundades regeringarnas samarbetsorgan Nordiska ministerrådet. Inom kultursamarbetet fanns barnoch ungdomsfrågor med tidigt. Det nordiska kulturavtal som trädde i kraft i januari 1972 talar om att främja "... verksamheten inom föreningar och organisationer med allmänkulturella syften, däribland också inom ungdoms- och idrottsarbete...". Nordiska kulturfonden inrättade snart bidrag till samarbete mellan ungdomsorganisationer, också utanför det direkta kulturområdet. Ministerrådet utredde samarbetet på barnkulturområdet och i Nordens hus i Reykjavík, som invigdes1968, prioriterades barn och unga från allra första början. Det blev det första av fem nordiska hus och institut som finansierades av Nordiska ministerrådet.

1900-talet var händelserikt på många sätt: ett århundrade av krig, demokratisering och nya perspektiv, rymdresor och miljöförstöring. Den svenska författaren Ellen Key utnämnde tidigt seklet till "barnets århundrade". På många områden har vackra ord inte följts upp med handling - barn- och ungdomsfrågorna har fått ta det utrymme som blivit över. Men relativt tidigt tog ändå nordisk politik fasta på barns och ungdomars välfärd, och med tiden också deras rättigheter.

Om 1900-talet inte blev barnets århundrade var 1979 i alla fall FN:s internationella barnår. Dess genomslag i Norden berodde kanske lika mycket på lojalitet mot FN-systemet som intresse för ämnet - effekten blev i alla fall att barn- och ungdomsfrågorna hamnade högre upp på den politiska dagordningen. Så blev barnåret ett steg i en utveckling där frågorna tagit formell plats i det nordiska samarbetet, en utveckling som skulle leda bortom frågor om barns utbildning eller kultur riktad till ungdomar - till insikten om barn och unga som medborgare med rättigheter. 


\section{BARN OCH UNGA - ETT EGET OMRÅDE}

Barn- och ungdomspolitiken utvecklas i det nordiska samarbetet. Strax efter att de nordiska institutionerna grundats inleds en process där man går från att se barn-och ungdomsfrågor som avgränsade, "mjuka" sakfrågor till att se dem som rättighetsfrågor som gäller alla sektorer, och i takt med detta blir formerna för arbetet tydligare.

Nordiska ministerrådet är flera råd, uppdelade efter regeringarnas departementsområden. I denna struktur sorterades tidigt barn- och ungdomsfrågorna in under kulturministrarna. Kanske kan man säga att frågorna om barns och ungas kultur banade väg för perspektiv som handlade om barns och ungas generella rättigheter. Från kultursektorn kunde Nordiska ungdomskommittén, NUK, och andra aktörer i Nordiska ministerrådet ta avstamp när man med tiden siktade bredare och längre. Något som resulterade i formella grunder. NUK:s stadgar från 1989 slår fast att "Nordiska Ungdomskommittén är Nordiska Ministerrådets rådgivande och koordinerande organ i nordiska och internationella barn- och ungdomspolitiska frågor. Kommitténs verksamhetsområde innefattar alla ministerrådets sektorer."

Det handlade alltså inte endast om fritidsaktiviteter eller vissa "mjuka" områden, utan om alla. Frågan var förstås hur man skulle få administrationer som arbetar med fiske-, energieller bostadsfrågor i ministerrådet att arbeta utifrån ett barn- och ungdomsperspektiv. NUK arbetade inte ensamt med dessa frågor, men var det enda organ i ministerrådet som hade i uppgift att göra det över alla sektorer. Kommittén bestod av 13 personer, utsedda av kulturministerrådet. Tre var utan rösträtt och kom från de självstyrande områdena Färöarna, Grönland och Åland, och sedan fanns det två från varje land: en som representerade landets myndigheter på barn- och ungdomsområdet och en från landets barn- och ungdomsorganisationer. I NUK hade både myndighetspersonerna och ungdomsrepresentanterna rösträtt - en modell som kallas co-management och som mötte en del höjda ögonbryn inom ministerrådet. I barn- och ungdomspolitiska sammanhang var modellen ganska vanlig.

- Klart att man måste ha med ungdomarna. Så jobbade man på många håll, från fritidsgårdar till departement, kommenterar Joachim Clausen i dag. Han var dansk medlem i NUK under 1990-talet och anställdes senare som ansvarig tjänsteman - rådgivare - i NUK:s arbete. 
Inom kulturområdet arbetade NUK jämsides och ibland tillsammans med en ledningsgrupp för barn- och ungdomskulturfrågor, BUK. Många blandade ihop dem, men skillnaden var stor: NUK:s uppgift och ansvar var hela ministerrådets sektorers barn- och ungdomspolitik. Men det är en sak att skriva in stora ambitioner i stadgarna, en annan att förverkliga dem.

- Det var jättesvårt att få till det tvärsektoriella tänkandet, och det hängde väldigt mycket ihop med att NUK var placerat hos kulturministrarna - det gjorde ju att man i andra delar av ministerrådet tänkte "det där är kulturfrågor", kommenterar Joachim Clausen.

Det var alltså svårt för NUK att fylla den stora roll man hade givits. Men massor av projekt och aktiviteter genomfördes. I ministerrådets plan- och budgetdokument från 2002 beskrivs 1990-talets satsningar på barn- och ungdomsområdet som omfattande. Man gav bidrag till organisationer som gjorde konkreta aktiviteter och arbetade med Nordens hus och institut, som hade en tydlig prioritering av barn och unga i sina verksamheter. Inom ministerrådet utvecklades utbytesprogram, projekt och nätverk som utvecklades för ökade kontakter över landsgränserna, och man satsade på att stärka barns och ungdomars egen kultur, samt sådan kultur som vuxna gjorde för barn och unga.

1979 var FN:s internationella barnår, 1989 antogs FN:s barnkonvention. De tio åren däremellan förändrades världen och Europa, och de nordiska länderna påverkades starkt. Det nordiska samarbetets former och strategier blev tydligare, och processen mot tydligare prioritering av barn och unga fortsatte, inom såväl ministerrådets verksamhet som till exempel Nordiska kulturfonden. Från och med FN:s barnkonvention blev det allt svårare att bortse från barns och ungas rättigheter. I Barnkonventionens 12:e artikel står det följande om staternas plikt att tillförsäkra barns rätt att uttrycka sina åsikter i alla frågor som rör barnet: "För detta ändamål skall barnet särskilt beredas möjlighet att höras, antingen direkt eller genom företrädare eller ett lämpligt organ och på ett sätt som är förenligt med den nationella lagstiftningens procedurregler, i alla domstols- och administrativa förfaranden som rör barnet." Nordiska rådet rekommenderade snart ministerrådet att utarbeta särskilda nordiska uppföljningsplaner utifrån konventionen.

Den här utvecklingen påverkade Nordiska ungdomskommittén. Den levde i ett dilemma: uppgiften var stor, men placeringen inom kultursektorn och alltför knappa resurser 
begränsade möjligheterna. Kommittén sökte en roll som handlade om den större bilden: hur barn och unga hade det, i Norden. I slutet av 1990-talet tillsattes en arbetsgrupp inom Nordiska rådet, med uppgift att undersöka just detta. Frågan de ställde var vilka möjligheter och svårigheter barn och unga mötte i Norden, och deras rapport var tydlig och nedslående: på många områden tog man i de nordiska länderna inte alls hänsyn till barns och ungas perspektiv. Till Nordiska ministerrådet skickade arbetsgruppen ett recept - just det som var NUK:s uppgift: tvärsektoriellt arbete. NUK tog passningen, höjde blicken och började arbeta med en handlingsplan som gällde över alla sektorer. Från kommitténs möte på Färöarna 2000 skickade man handlingsplanen "Norden in i ett nytt årtusende" till kulturministrarna, som antog den i juni året därpå. Bland handlingsplanens övergripande mål fanns stora framtidsfrågor - att säkra en hållbar utveckling, tolerans och etnisk mångfald - och fokus på särskilt utsatta barn och unga. De fyra första punkterna visade på perspektivet att barn och unga är medborgare med rättigheter:

- Barns och ungas delaktighet och inflytande

- Barns och ungas egna kulturuttryck och förstärkning av den nordiska identiteten

- Ungas rätt till kvalificering

- Jämlikhet mellan generationer, kön och regioner i Norden.

I efterhand ser arbetet med handlingsplanen ut att ha påverkat en bredare process i ministerrådet. 2001 hölls ett toppmöte och seminarium i Finland om "Ungas deltagande och delaktighet i beslutsfattande på regional- och lokalnivå". I augusti 2002 möttes ministrar från olika departement i de nordiska ländernas regeringar till en konferens om ungdomars inflytande. Man möttes i Porsgrunn, en norsk kommun som utifrån FN:s barnkonvention gått långt i att involvera ungdomar och barn i beslutsfattandet, och ett motto formulerades under konferensen: Nothing about us, without us.

I april 2002 förändrades NUK:s stadgar, med längre mandatperioder för att ge kommittén större möjligheter att arbeta utifrån handlingsplanen, med lite mer tyngd till ungdomsrepresentanterna och rätt för Samiska ungdomsrådet att närvara på kommittémötena. I Nordiska ministerrådets plan- och budgetdokument inför 2002 är det mycket energi i texten när man skriver om barn och unga som speciellt fokus för alla sektorer: "En av de viktigaste frågorna för det nordiska samarbetet är att säkerställa att barn och unga har en god uppväxtmiljö, goda levnadsvillkor och samma rättigheter". 
Det är skjuts i frågorna. Många sektorer formulerar sig, åtminstone på någon nivå, om vad deras verksamhet och förslag betyder ur ett barn- och ungdomsperspektiv. En del siktar på barns och ungas konkreta livssituation, annat handlar om att barn och unga finns bland dem som berörs av frågorna. Det handlar om bostadspolitik, fiskeripolitik, förebyggande av narkotikamissbruk bland unga, att fler unga ska kunna delta i nordiska idrottsevenemang. Det är skolsamverkan, miljöprojekt, satsningar i Baltikum och konsumentrollen: "Barn och unga är en konsumentgrupp som är särskilt utsatt för reklam och produktinformation, och det är därför speciellt viktigt att utveckla konsumentkrav som säkrar att barn och unga är i stånd att göra självständiga val ...". Kultursektorn fortsätter sina satsningar på språkförståelse och en nordisk ungdomsorkester, på film och medier, och trycker på barns och ungas medbestämmande - de ska själva påverka verksamhetens innehåll.

"Norden in i ett nytt årtusende" berättar på det sättet om ett nordiskt barn- och ungdomssamarbete på väg till - men ännu inte framme vid - en övergripande nivå, och om en ungdomskommitté mitt i steget mellan två roller, möjligen fortfarande med mer fokus på egna aktiviteter än på den övergripande rollen.

Under denna tid bearbetades NUK:s roll. Uppgiften som kommittémedlem, resonerade man nu, kunde inte handla om att bara sitta som representant för sin organisation eller sitt land och dess intressen, och absolut inte för att säkra pengar till sina organisationer, utan för att göra verkligt samarbete. Från januari 2004 lade man ut den administrationen på ett programkontor för att få mer tid för att arbeta utifrån handlingsplanen - en kursändring i riktning mot ett mer krävande, mindre konkret arbete, för att på allvar påverka politiska processer på alla områden. Från den svenska myndigheten Ungdomsstyrelsen (numera Myndigheten för ungdoms- och civilsamhällesfrågor) beställde NUK en utvärdering av handlingsplanen. De fick tillbaka en kritisk text, med en önskelista inför nästa försök: tydligare syftesbeskrivningar och därmed tydligare roll för NUK, och hårdare prioriteringar så att målen kunde följas upp och arbetet spela roll i ministerrådet och för Norden. För NUK, som skulle göra jobbet, såg läget osäkert ut. Kulturministerrådet hade omorganiserat och lagt ner många ledningsgrupper, bland andra den för barn- och ungdomskultur, BUK.

Joachim Clausen berättar hur dåvarande generalsekreteraren för ministerrådet, Per Unckel, träffade NUK på ett möte i Stockholm. Han hade en rak fråga: "Jag vill veta varför NUK är viktig, varför ska den inte läggas ned?". NUK - framför allt ungdomsrepresentanterna - 
svarade upp, med goda argument. Efter ett möte med samarbetsministrarna blev det klart: i stället för att försvinna skulle kommittén få nya möjligheter, i en friare roll, under nytt namn, och med ny plats i organisationen - direkt under Ministerrådets samarbetsministrar. 


\section{BARN- OCH UNGDOMSFRÅGORNA I CENTRUM AV DET}

\section{NORDISKA SAMARBETET}

\section{Med en övergripande strategi och en centralt placerad barn-och ungdomskommitté på plats ökar barn- och ungdomsfrågornas tyngd i den nordiska politiken.}

Det nordiska samarbetet handlar om nordisk nytta. Om insatser som gynnar Norden som område, och som man gör bättre tillsammans än var för sig. Det finns olikheter mellan länderna och de självstyrande områdena i det nordiska samarbetet. Men likheterna i Norden är stora, och bland de områden där det varit ganska lätt att mötas finns välfärdsmodellerna och synen på barn och unga. Norden har legat långt framme när det gäller att utveckla synen på barns och ungas rättigheter som ett grundläggande perspektiv på samhället.

I dag finns barn- och ungdomsfrågorna mitt i det nordiska samarbetet. Två viktiga steg åt det hållet togs av Nordiska ministerrådet i mars 2006. Det ena gällde kommittén, som då bytte namn från NUK till Nordiska barn- och ungdomskommittén, NORDBUK. Ett namnbyte kan verka vara en formalitet, och NORDBUK har många likheter med föregångaren, med lika många medlemmar och samma grundläggande uppgift: att vara ministerrådets rådgivande och samordnande organ i barn- och ungdomspolitiska frågor. Men NORDBUK var något nytt. Dels underströk det nya namnet att kommittén sysslade med både barn- och ungdomsfrågor, dels försökte man redan från början ge representanterna för de självstyrande områdena Färöarna, Grönland och Åland - rösträtt i kommittén. Det kunde bli verklighet först efter en process inom ministerrådet som 2007 ledde fram till Ålandsdokumentet. I NORDBUK:s stadgar från september 2007 var representanterna på detta sätt jämställda, något som var ett steg framåt både för de självstyrande områdena och för kommittén, vars tyngd ökade. Men den största förändringen handlade om NORDBUK:s plats i ministerrådsorganisationen: även om kommitténs budget, av tekniska skäl, fortfarande ligger under kulturministrarna, sorterar själva kommittén sedan 2007 direkt under samarbetsministrarna i MR-SAM.

NORDBUK:s plats i hjärtat av ministerrådet är en tydlig signal om barn- och ungdomsperspektivet som en gemensam angelägenhet, och detta budskap underströks av ett annat steg som Nordiska ministerrådets samarbetsministrar tog den 1 mars 2006 då man antog "Strategi för barn och unga i Norden", ett dokument där man för första gången lyfte upp 
barn- och ungdomsperspektivet i ett styrdokument som gäller för hela ministerrådet. Strategins inledande vision börjar med ett stolt och högt sikte: "Norden ska vara den bästa platsen i världen för barn och unga". Som "unga" räknas i Nordiska ministerrådets sammanhang oftast alla upp till 25 år, med barn menar man de som är under 18 år. Men hur ska då Norden bli den bästa platsen för människor i dessa åldrar?

Strategins svar är de mål som formuleras: att främja barns och ungas goda levnadsvillkor och deras inflytande. Rättighetsperspektivet är grundläggande i strategin, med referenser till FN:s barnkonvention och beskrivningar av barns och ungas välbefinnande som en "förutsättning för framtida hållbar utveckling i Norden". Man specificerar både de levnadsvillkor som ska vara goda - det handlar om rätt till utbildning, trygghet, hälsa och utvecklingsmöjligheter och vad inflytandet gäller: påverkan på sina egna liv men också på sin närmiljö och samhällsutvecklingen.

Inom Nordiska ministerrådet finns, förutom de koordinerande samarbetsministrarna i MRSAM, tio ministerråd. I den uppdaterade versionen av strategin, som antogs 2009, prioriteras vissa barn- och ungdomsfrågor som kunskap om klimatförändringarna, sundare matvanor, nya metoder för ungas deltagande i demokratiska processer och att fler unga ska utbilda sig efter grundskolan. De flesta ministerråd har ansvaret för någon eller några av de prioriterade frågorna, men oavsett det har alla samma ansvar för att anlägga ett barn- och ungdomsperspektiv i sitt arbete. Vid varje beslut ska man analysera hur barn och unga påverkas. Dessutom ska alla sektorer formulera mätbara mål för sin verksamhet utifrån strategin för barn och unga.

Nästan ingen ifrågasätter det nordiska samarbetet, men kunskaperna om det hos en genomsnittlig invånare i Norden är små. Lite på samma sätt är det med barn- och ungdomsfrågorna i det nordiska samarbetet: ingen avfärdar dem, självklart ska barns och ungas perspektiv tas tillvara. Men just för att alla tycker likadant kan det bli svårt att föra en kritisk diskussion om vad som händer och inte händer. De fina, gemensamma åsikterna kan nästan bli ett hinder - likaväl som de, när prioriteringarna blir verkliga, kan bli grund för handling som verkligen spelar roll.

För att nå dit är strategin ett verktyg som sätter en miniminivå för hela organisationen. Varje sektor ska varje år rapportera vad man gjort i förhållande till strategin - alltså måste någon i 
varje ministerråd, åtminstone i någon mån, ägna sig åt barn- och ungdomsperspektivet. NORDBUK samlar dessa rapporter, och har uppgiften att följa upp strategin och utifrån årliga rapporter både utvärdera de insatser som gjorts och föreslå ändringar. Det slutliga, övergripande samordningsansvaret ligger hos samarbetsministrarna och deras nordiska samarbetskommitté.

NORDBUK är alltså inte ensam aktör i barn- och ungdomsfrågorna inom Nordiska ministerrådet, men däremot den som har tydligast uppgift att bevaka och driva på. Kommittén har tretton medlemmar, och en sammansättning där åtta är myndighetsrepresentanter från de nordiska länderna och de självstyrande områdena och fem är representanter från ländernas ungdomsorganisationer. NORDBUK har samma - i ministerrådssammanhang unika - co-management-modell som NUK hade, med ungdomsrepresentanter som har samma rösträtt som regeringarnas utsända. Kommittén sammanträder två till tre gånger om året. På ministerrådets sekretariat arbetar en rådgivare och en koordinator med NORDBUK - fast båda har även andra ansvarsuppgifter. Mellan sammanträdena arbetar också kommitténs arbetsutskott med representanter för innevarande och nästkommande års ordförandeland. Ordförandeskapet i NORDBUK roterar årsvis mellan länderna, ett system som ger ordförandelandet extra ansvar och utrymme. Inte minst gäller det aktivitetsplanen.

Den antas inför varje år och beskriver på kort sikt och konkret vad NORDBUK ska göra. Den utgår från handlingsplanen som gäller fyra år i taget och är mer övergripande. När föregångaren NUK:s handlingsplan skulle ersättas tog man utvärderingens kritik, med önskemål om tydligare rollfördelning och prioritering, på allvar. NORDBUK:s handlingsplan blev också ett mindre ensamt dokument: från och med 2006 har den ministerrådets "Strategi för barn och unga" som utgångspunkt. För att komma närmare strategins mål har NORDBUK två sikten: dels det tvärsektoriella uppdraget att koordinera barn- och ungdomsfrågorna inom hela ministerrådet, dels egen verksamhet.

I handlingsplanerna från 2006 till 2013 är den egna verksamheten aktiviteter som faller utanför andra fackområden inom ministerrådet, och så pekar man ut några prioriterade områden. 2008 identifierar NORDBUK till exempel ett behov av att stärka sitt barnrättsliga perspektiv, året efter lyfter man fram arbetet med barn och unga som aktiva nordiska medborgare, mänskliga rättigheter och nordisk språkförståelse. Viktiga prioriteringar har 
också varit stöd till barns och ungas egen organisering, och utveckling av metoder för barns och ungas deltagande i demokratiska processer. Dessa frågor arbetar man med genom bidrag till barn- och ungdomsorganisationers nordiska samarbete, dels till projekt som läger, festivaler eller publikationer, dels till själva samarbetet och kontaktbyggandet mellan ungdomsorganisationer i Norden. Själva bidragsadministrationen sköts av externa aktörer sedan 2013 Kulturkontakt Nord - men NORDBUK drar upp riktlinjer, följer upp och arbetar med bidragens tillgänglighet.

En av kommitténs uppgifter är att ta tillvara och sprida kunskap och forskning på barn- och ungdomsområdet. Temainriktning och metoder växlar. I perioder har man haft en anställd forskningskoordinator och tanken är hela tiden att sammanföra forskare med både ungdomsorganisationerna och den politiska nivån. Mellan 2011 och 2013 har ungdomsarbetslöshet varit i fokus för NORDBUK:s forskningskoordinator. År 2012 arrangerades bland annat seminarium om "Unga utanför", 2013 om unga på nätet under festivalen Nordic Cool i Washington - och resultatet av forskningssatsningarna har bland annat synts i publikationer.

NORDBUK:s koordinerande och rådgivande roll är vagare, men innebär ett stort mandat. Inte minst innebär uppgiften att analysera och utvärdera hur ministerråden gör verklighet av strategin. Den uppgiften är central i NORDBUK:s tvärsektoriella uppdrag, men den är fortfarande ganska ny, och NORDBUK är mitt i processen för att hitta formerna för den. Hur central rollen verkligen blir beror på många faktorer.

NORDBUK:s möjligheter beror förstås också på vilken betydelse man ges - och tar - i samspelet i ministerrådet. Man kan ta egna initiativ, men är också beroende av att man i alla ministerrådets sektorer - och nationella myndigheter och andra instanser som kommer i kontakt med Nordiska ministerrådet - känner till och räknar med NORDBUK, att man ser behovet av kunskap om barn- och ungdomsperspektiv och frågar efter den. För att detta ska fungera behöver den rådgivare som arbetar för NORDBUK vara informerad, och kommittén måste följa med och veta vad som händer i sektorerna. Under en period delade NORDBUK upp sig i undergrupper för att kunna hålla kontakt med ministerrådets olika fackavdelningar och resultatet av detta blev ett nätverk där man kunde stämma av läget vad gäller barn- och ungdomsfrågor, och på det sättet sprida kunskap och idéer mellan ministerrådets sektorer. 
I dag är detta nätverk formaliserat och utgör en arbetsgrupp, med fokus på återrapportering i förhållande till strategin.

I dag finns strukturen för arbetet med barn- och ungdomsfrågorna inom Nordiska ministerrådet på plats: strategi, NORDBUK, handlingsplaner, aktivitetsplaner och olika kontaktvägar inom organisationen. Dessutom finns höga mål och ambitioner - från strategins övergripande vision om Norden som bästa plats för barn och unga, till ministerrådsövergripande prioriteringar av frågor om unga och hedersrelaterat våld och ungas utanförskap, som betonats under senare år, samt de som görs i enskilda sektorer som jämställdhetsområdets aktiviteter kring temat "kön och unga", eller NORDBUK:s egna prioriteringar.

I årsrapporter och plan- och budgetdokument, och i samtal med folk i Nordiska ministerrådet märks det: i slutändan blir det massor av konkret verksamhet. Det handlar om utbytesprogram, ungdomsorkestrar och ungdomsarbetslöshet, baltiska demokratiprojekt, program mot barnfetma och satsningar på förståelse av grannländernas språk. 0m nordiskproducerade datorspel, barnfilmfestivaler och ungas sexuella hälsa. Man arbetar för unga idrottare, unga vulkanforskare, unga professionella konstnärer, unga politiskt aktiva, unga missbrukare och unga sommarjobbare - i massor av projekt och verksamheter möts unga från Nordens länder och självstyrande områden, och dessutom är kontakterna med Baltikum och nordvästra Ryssland många. Detta är verksamhet som görs eller på olika sätt möjliggörs av Nordiska ministerrådets olika delar.

Kulturministrarna stöder ungdomsfilm, miljö- och naturområdet gör ungdomsprojekt kring klimatfrågorna, projektet "ny nordisk mat" inom hälso- och välfärdssektorn har fokus på barn och unga. Vid Nordens hus och institut, de kulturinstitutioner som finns på Färöarna, Grönland, Island, Åland och i Helsingfors, har man mycket konkret verksamhet. De har sedan lång tid ett tydligt fokus på barn och unga och jobbar med många olika kulturella uttryck. NAPA, i Grönlands huvudstad Nuuk, står till exempel för kulturinslag på Arctic Winter Games, i Reykjavík har man haft arkitekturworkshops. I Tórshavn, Färöarna, arbetar man med film till stöd för unga färöiska filmproducenter, och på Åland och i Finland med skrivartävlingar och storytelling. Det görs teater, dans- och rockfestivaler och kulturprojekt för barn och unga med funktionshinder i en konkret och välintegrerad verksamhet. 
Många projekt och verksamheter som NORDBUK initierar görs i samarbete med andra aktörer. Till exempel lanserades 2009 webbsidan "Norden förr och nu" i samverkan med Danmarks radio. Den är ett verktyg för både grannspråksförståelse och teman som nordisk historia och mänskliga rättigheter, och riktar sig bland annat till skolor. "Det levande biblioteket", eller "människobiblioteket", var ett mycket framgångsrikt projekt som demonstrerade vad mänskliga rättigheter handlar om. I verksamheten fanns människor som folk generellt har många fördomar om "till utlån", för nya möten och ny dialog. Idén kom från de unga själva, prövades första gången på Roskildefestivalen år 2000 och genomfördes av NORDBUK i samarbete med Europarådet, som också tog initiativ till att göra en bok om idén. Tillsammans med det norska forskningsinstitutet NOVA och de nordiska barnombudsmännen, och med anledning av att FN:s barnkonvention fyllde 20 år, publicerades i november 2009 en publikation med modeller för hur barn och unga aktivt kan göras delaktiga i samhällsutvecklingen. 


\section{NU - OCH SNART}

Under Sveriges ordförandeskap 2013 hade NORDBUK starkt fokus på ungas utanförskap, framför allt när det gäller arbetslöshet. Det har till exempel märkts i att den halvtidsanställde forskningskoordinatorn som jobbar för NORDBUK har spritt kunskap med detta fokus och under året gjordes en förstudie till en nordisk barn- och ungdomsbarometer med fokus på barnfattigdom.

De nordiska statsministrarnas jobbtoppmöte i maj följdes ett halvår senare upp med en stor konferens under temat "Fler unga i arbete i Norden", arrangerad av svenska myndigheten Ungdomsstyrelsen (numera Myndigheten för ungdoms- och civilsamhällesfrågor).

Konferensen syftade till att bland politiker och tjänstemän sprida goda exempel på hur man kan få fler unga i arbete, och bland ämnena fanns tidiga avhopp från utbildning, ungas ohälsa som ett hinder för arbete, att hitta arbete inom kreativa näringar och att tänka hela Norden som arbetsmarknad.

NORDBUK samverkar bland annat med motsvarande instanser inom EU och Europarådet och med nordiska aktörer som Ungdomens nordiska råd som är kopplat till Nordiska rådet. I april möttes de nordiska och baltiska landsråden och ungdomsorganisationerna för en konferens i Stockholm, där man diskuterade ungdomspolitik och ungas inflytande och där syftet var lika mycket att mötas som att stärka. En uppföljning är planerad till 2014.

NORDBUK och Norden syntes också i Washington, USA, under festivalen Nordic Cool 2013 på Kennedy Art Center. Där visades konst och kultur från Norden och bland aktörerna fanns Nordiska kulturfonden - och NORDBUK - som tillsammans med ministerrådets ämbetsmannakommitté för jämställdhet arrangerade ett seminarium i anslutning till festivalen. Ämnet när 120 personer träffades på svenska ambassaden i Washington var Youth, gender and online exposure och idén var att höja kompetensen bland dem som arbetar med unga. I publik och panel diskuterade och funderade man över utsatthetsrisker när unga använder internet, och skillnaderna i hur dessa drabbar flickor respektive pojkar.

I december 2013 beslutade samarbetsministrarna, på förslag från ministerrådets generalsekreterare, att ge sekretariatet i uppgift att under 2014 se över och föreslå revideringar i strategin för barn och unga. Samtidigt antog man NORDBUK:s handlingsplan för 
2014-2017, en handlingsplan som sätter fokus på barns och ungas utanförskap.

Utvärderingen av den föregående handlingsplanen lyfte fram bra insatser, men efterlyste mer konkretion och tydligare prioriteringar. Visionära mål och allmänna formuleringar om att "främja" och "verka för" ger inte mycket vägledning, menade utvärderingen, i stället behövs tydlighet om vad som menas med det tvärsektoriella, hur NORDBUK ska bidra till strategins mål och hur aktivitetsplaner hänger ihop med årsrapporterna utifrån strategin.

Den nya handlingsplanen innebär ett nytt, stort steg i en utveckling av det nordiska samarbetet kring barn- och ungdomsfrågor som under 2000-talet har blivit alltmer kvalificerat och strategiskt inriktat. Det första huvudområdet har rubriken Främja tvärsektoriell samverkan - integrering av barn- och ungdomsperspektiv inom det nordiska samarbetet, med särskilt fokus på barns och ungas utanförskap. Det koordinerande och rådgivande uppdraget för ministerrådets barn- och ungdomsinsatser är inte nytt, men i och med att man justerade "Strategi för barn och unga i Norden" 2009 kvalificerades uppdraget: nu skulle sektorerna formulera mätbara mål för barn- och ungdomsområdet och analysera vilka konsekvenser verksamheten har för barn och unga. NORDBUK å sin sida fick i uppgift att inte bara samla ihop beskrivningar av vad som gjorts under året, utan också analysera insatserna - och föreslå förändringar - för att uppfylla strategin. Inget av dessa uppdrag har riktigt fullgjorts, men den nya handlingsplanen tar sikte på formerna för detta arbete och för att kunna göra bättre utvärderingar har NORDBUK redan hösten 2013 arbetat fram en ny, mer avgränsande och konkret enkät till sektorerna.

Det andra huvudområdet är Kunskap om barns och ungas utanförskap i Norden. Denna kunskap behöver spridas bland myndigheter och organisationer och för att det ska ske på ett bra sätt vill man även här arbeta med formerna och delta i erfarenhetsutbyten mellan nordiska länder och - i mån av resurser - i internationella sammanhang.

Slutligen har man prioriterat Barns och ungas organisering, inflytande och delaktighet $i$ demokratiska processer. NORDBUK:s planerade insatser handlar bland annat om att rikta bidrag till stärkt samverkan mellan barn och unga, se till att ta tillvara lärdomar från de aktiviteter som får stöd samt arbeta för att barn och unga involveras inom Nordiska ministerrådets olika sektorer. 
Steg för steg har arbetet med barn- och ungdomsfrågor gått framåt i Nordiska ministerrådet. Perspektivet har breddats från kulturområet till alla områden, man har alltmer sökt sätt att arbeta som inte bara är för, utan även med och $a v$ barn och unga, och alltmer orienterat sig mot ett rättighetsbaserat perspektiv. I denna process har kommittéerna - NUK, BUK och nu NORDBUK - varit viktiga aktörer. Den första tvärsektoriella handlingsplanen 2001 var en viktig punkt, liksom den första strategin för barn och unga i Norden och NORDBUK:s bildande.

Den nya handlingsplanen är ett steg till, och siktar tydligt på att hitta redskap och en realistisk nivå för verkliga resultat. På det sättet vill NORDBUK spela en roll i det nordiska samarbetet, vars många områden också spelar roll för barn och unga som medborgare i ett Norden där länder och människor ofta löser problem och uppgifter bättre i samarbete, över nations- och kulturgränserna.

Under 2014 antog de nordiska samarbetsministrarna en ny vision gällande det nordiska samarbetet. Denna vision består av fyra delar: ett gränslöst Norden, ett innovativt Norden, ett synligt Norden och ett utåtriktat Norden. Samtidigt pågår en moderniseringsprocess inom Nordiska ministerådet, en process som lyfter fram vikten av tvärsektoriellt samarbete och en ambition av att stärka samverkan mellan sektorerna. Barn- och ungdomspolitik är ett område som berör många sektorer och påverkar utvecklingen av det nordiska samarbetet i framtiden. 
1921: Nationernas förbund beslutar att Åland ska vara en del av Finland och få självstyrelse.

1944: Island självständigt från Danmark.

1948: Färöarna blir ett självstyrande område under Danmark.

1952: Nordiska rådet grundas som ett samarbetsorgan för de nordiska parlamenten.

23 mars 1962: Helsingforsavtalet sluts mellan de nordiska länderna. I avtalet finns (i artikel 16, under rubriken Socialt samarbete) en formulering med som säger att "de fördragsslutande parterna skola ytterligare utveckla samarbetet beträffande hälso- och sjukvård, nykterhetsvård samt vård av barn och ungdom."

1966: Nordiska kulturfonden bildas.

24 augusti 1968: Nordens hus invigs i Reykjavík. Barn och ungdom är från början ett prioriterat område. 1971: Nordiska ministerrådet grundas, ett organ för samarbete mellan de nordiska regeringarna. Helsingforsavtalet revideras för att göra ministerrådet till det officiella samarbetsorganet för de nordiska regeringarna.

1972: Nordiska ministerrådets sekretariat konstitueras.

Januari 1972: Det nordiska kulturavtalet träder i kraft med uppgift att stärka och intensifiera kulturellt samarbete samt vidareutveckla den nordiska kulturgemenskapen. I avtalet nämns ungdomar. Artikel 5e framhåller "(...) främjande av verksamheten inom föreningar och organisationer med allmänkulturella syften, däribland också inom ungdoms- och idrottsarbete (...)".

Tidigt 1970-tal: Nordiska ungdomskommittén (NUK) bildas (enligt svensk regeringsproposition 2004).

1975: Nordiska ministerrådet tillsätter ett utskott/en arbetsgrupp för att utreda närmare samarbete på barnkulturområdet. Arbetsgruppen lade fram sin rapport 1978.

1976: Nordiska kulturfonden etablerar en särskild stödordning för Nordiskt ungdomssamarbete, något som hade att göra med ett allmänt samarbete mellan ungdomsorganisationer också utanför det direkta kulturområdet.

1979: Grönland får regionalt självstyre, "hemstyre", under Danmark.

1979: $F N$ :s internationella barnår - viktigt för de nordiska länderna med deras starka lojalitet mot $F N$. Temaåret uppmärksammades i det nordiska samarbetets olika organisationer.

1983: Nordens hus i Tórshavn, Färöarna, står färdigt.

1985: FN:s ungdomsår.

1985: Nordens institut på Åland invigs.

1987: NAPA - Nordens institut i Grönland öppnar. Med kontor i Kulturhuset/Katuaq i Nuuk, Grönland.

1988: Nordisk handlingsplan för nordiskt kulturellt samarbete presenteras. Nämner särskild arbetsgrupp för barnkultur.

1989: FN:s barnkonvention antas.

27 november 1989: Stadgar fastställs för Nordiska ungdomskommittén, NUK.

1990-talets början: Nordiska rådet rekommenderar Nordiska ministerrådet att utarbeta särskilda nordiska uppföljningsplaner kring FN:s barnkonvention. 
1993: Nordiska ministerrådet föreslår en nysatsning och en ny struktur inom kultur, utbildning och forskning. I implementeringen av detta får satsningar på barn och ungdomar en tydligare prioritet, vilket påverkar också t.ex. Nordiska kulturfonden.

1993: Arbetsordning för Nordiska ministerrådet som slår fast samarbets- och statsministrarnas roll, liksom NSK:s - de bistår MR-SAM och får uppdrag direkt från statsministrarna, bereder frågor till MR-SAM, fattar vissa beslut, fastställer arbetsordning, utnämner avdelningschefer osv.

1995: NUK utvärderas (http://libris.kb.se/bib/2129748).

4 december 1995: Kulturministrarna beslutar att öronmärka 80 procent av NUK:s budgetmedel till stödordningen för barn- och ungdomsorganisationer. Detta beslut begränsade kraftigt NUK:s möjligheter att bedriva verksamhet på eget initiativ.

1996: Handlingsplanen för nordiskt barn- och ungdomskultursamarbete 1996-2000, "Ett kommande Norden".

Februari 1996: Förslag till stadgar för Ledningsgruppen för nordisk barn- och ungdomskultur - BUK, Nordiska Ministerrådets rådgivande, koordinerande och initierande organ i nordiska och internationella barn- och ungdomskulturella frågor. Fanns jämsides med NUK, under ministerrådet för kultur.

6 mars 1996: Stadgar för NUK fastställs.

1998: En arbetsgrupp tillsätts inom Nordiska rådet för att ge en samlad bild av barns och ungas möjligheter och svårigheter i de nordiska länderna samt för att komma med förslag. I sin rapport pekade man senare på att man i länderna på flera områden lät bli att ta hänsyn till barn- och ungdomsfrågor. Där, precis som i det nordiska samarbetet, var perspektivet ganska snävt: barn- och ungdomsfrågor sorterades in under "kultur". För att stärka arbetet efterlystes en tvärsektoriell handlingsplan. Detta var ett incitament för NUK:s handlingsplan som antogs 2000.

1999: Island ordförandeland i NUK. Förberedelser inför ny handlingsplan.

2000: Vid ett möte på Färöarna, under danskt ordförandeskap, tar NUK beslut om handlingsplanen "Norden in i ett nytt årtusende" - en tvärsektoriell handlingsplan för nordiskt barn- och ungdomspolitiskt samarbete.

2001: "Norden in i ett nytt årtusende" träder i kraft. Toppmöte och seminarium i Finland: "Ungas deltagande och delaktighet i beslutsfattande på regional- och lokalnivå". Konferens om barns och ungas livsvillkor i glesbygd i Norden, dess närområden och Europa. Deltagare bl. a. från Baltikum och nordvästra Ryssland.

5 april 2002: Kulturministrarna tar beslut om förändring av NUK: stadgar med förlängd mandatperiod tre år i stället för två - med närvarorätt för Samiska ungdomsrådet, och med ungdomsorganisationsrepresentanten från nästkommande års ordförandeland i arbetsutskottet. Dessutom lyftes skrivningar om koordinering av uppföljning fram.

2002: NMR antar BUK:s nya handlingsplan för nordiskt samarbete om barn, unga och kultur, "Det unga Norden - gemenskap och mångfald".

9-11 augusti 2002: Tvärsektoriell ministerkonferens i Porsgrunn, Norge, om ungdomars inflytande.

Porsgrunn var den kommun i Norge som gått längst i att involvera ungdomar i alla beslut, med hänvisning 
till FN:s barnkonvention som säger att detta ska göras. Nothing about us, without us var det motto som formulerades därifrån.

September 2002: Flerkulturell mönstring med unga deltagare i Oslo.

1 januari 2004: Hanteringen av de bidrag som NUK är ansvarig för läggs ut på en extern aktör (CIRIUS). 2004/2005: I Nordiska kulturfondens årsberättelse påpekas i punkt 1.3: "Styrelsen prioriterar konst- och kulturprojekt som stimulerar aktiviteter för och med barn och ungdomar."

2005: Svenska Ungdomsstyrelsen utvärderar NUK:s handlingsplan. Kritik: den var för omfångsrik och för detaljerad.

1 januari 2006: Ledningsgruppen för barn- och ungdomskultur, BUK, läggs ned.

1 mars 2006: NUK byter namn till NORDBUK och sorterar hädanefter under samarbetsministrarna, MR-

SAM. Dessutom antar dessa ministrar "Strategi för barn och unga i Norden" som tydliggör frågornas plats i hela ministerrådsarbetet. Strukturen med strategin, årliga rapporter som utgår från den osv.

institutionaliserar frågorna så att de inte ska kunna prioriteras bort som "mjuka", "extra" eller mindre grundläggande frågor. För det tredje antas en handlingsplan för NUK/NORDBUK 2006-2009.

4 september 2007: NORDBUK får nya stadgar och NSK delegerar till NORDBUK ansvaret för att utarbeta NORDBUK:s stödordning, alltså riktlinjer för bidrag (förutsatt en årlig rapport från kommittén till NSK/MRSAM).

5 september 2007: Ålandsdokumentet antas och möjliggör att representanter från de självstyrande områdena i NORDBUK får rösträtt.

2009: FN:s barnkonvention fyller 20 år och NORDBUK ger i november, i samarbete med de nordiska barnombudsmännen, ut en publikation med bra exempel på hur barn aktivt kan göras delaktiga i samhällsutvecklingen.

2009: Justering av "Strategi för barn och unga i Norden". Webbplatsen "Norden förr och nu" lanseras i samarbete mellan Nordbuk och Danmarks Radio med stöd från Nordiska kulturfonden.

3 december 2009: Nordbuks handlingsplan 2010-2013 fastställs.

2010: Tvärfackliga arbetsgrupper inom NORDBUK - för kontakt med vart och ett av sekretariatets tre fackavdelningar.

Oktober 2010: Forskningskonferens om ungas välbefinnande och livsvillkor.

2010-2011: Studien "Nordisk ungdomspolitik i ett komparativt perspektiv" genomförs.

2011: Seminarium: "Indikatorer för den nordiska och europeiska barn- och ungdomssektorn".

Maj 2011: Fem unga nordbor mellan 18 och 23 år utses att ingå i den kommitté som ska besluta om vem som ska motta 3 miljoner danska kronor av Nordiska kulturfonden för att göra en nordisk kulturfestival för barn och unga 2014.

2011-2013: Forskningsstrategin antas och man anställer en ny forskningskoordinator, tema ungdomsarbetslöshet.

2012: NORDBUK arrangerar seminarier - "Unga utanför", "Ungdomar, demokrati och deltagande", "Kultur och identitet" samt två seminarier vid Nordiska rådets session i Helsingfors, bl. a. med fokus på vikten av barns och ungas involvering i det nordiska (kultur)samarbetet.

1 januari 2013: Hanteringen av de bidrag som NORDBUK ansvarar för läggs ut på Kulturkontakt Nord. 
2013: Seminarium om unga på nätet under Nordic Cool i Washington.

2013: Utvärdering av NORDBUK:s handlingsplan.

2013: Beslut om ny handlingsplan NORDBUK. Beslut om utvärdering av Strategin för barn och unga i Norden. Beslut om översyn av NORDBUK:s stadgar.

2014: Beslut om analys av NORDBUK:s organisering

Juli-augusti 2014: Nordic light 2014 - en vandrande barn- och ungdomskulturfestival genomförs som årets nordiska kulturevenmang, med stöd på 3 miljoner danska kronor från Nordiska kulturfonden. 